\title{
Role of Product Cause Fit in Cause Related Marketing Campaign Decisions
}

\author{
C.Kathiravan, R. Kanthiah Alias Deepak, V. Suresh, P. Mahalakshmi
}

\begin{abstract}
The research started with the aim to get a better understanding of Cause Related Marketing Campaigns (CRMC) from a whole perspective. In order get a complete understanding of the Cause Related Marketing Campaigns (CRMC), the element namely Product Cause Fit was studied. The Campaigns showed to the consumers like, $(P C F-1, P C F-2$, and $P C F-3)$ in order to understand the consumer's response. The consumers are moderately agreed with all three types of models. Hence their response to Cause Related Marketing Campaigns (CRMC) is moderate based on the mean values. Further the researcher found that there is a relationship between Product Cause Fit and Corporate Image. Also Corporate Image has direct influence on Purchase Intention. In this way researcher suggest the corporates to concentrate more while determining cause for Cause Related Marketing Campaign which determines the corporate image in the minds of consumers.
\end{abstract}

Keywords : Cause Related Marketing, Campaigns, Structural elements.

\section{INTRODUCTION}

$\mathrm{F}$ ast Moving Consumer Goods (FMCG) goods are also called as Consumer Packaged Goods (CPG). The products included in this category are which is used frequently for day to day life and with high return. In recent years, the effort of corporate's in sales promotion in this area is greater than before all over the world. This sector's products have less unit value and frequently required items. Indian FMCG industry is the biggest industry in the economic system and makes employment opportunities in various related activities. The FMCG market is set to expand from US\$ 11.6 billion dollars in 2003 to US\$ 33.4 billion dollars in 2015. The household consumption of most product groups like jams, skin related products and hair wash items in are comparatively less. It indicates the untouched market potential. The native Indian populations are growing, particularly the middle-class and the non-urban sections. It makes an opportunity to makers of labeled items to turn consumers to labeled items. In India 300 million people expected to move to prepared and packed meals by 2017, India needs around US\$ 28 billion dollars of

Revised Manuscript Received on July 22, 2019.

Dr.C.Kathiravan, Assistant Professor, Department of Business Administration, Annamalai University, Chidambaram, Tamilnadu E-Mail: kathirc@gmail.com

Dr. R. Kanthiah Alias Deepak, Corresponding Author, Assistant Professor Department of Business Administration, G.Venkatasamy Naidu College,Kovilpatti

V. Suresh, Doctoral Research Scholar, Dept. of Management Studies, Manonmanium Sundaranar University, Tirunelveli, Tamil Nadu, India.

P. Mahalakshm, Doctoral Research Scholar, Dept. of Management Studies, Manonmanium Sundaranar University, Tirunelveli, Tamil Nadu, India. financial commitment in the food-processing industry. The FMCG industry is significant factor to GDP. The FMCG industry is estimated to threefold from its currently determined value within 10 years of time. The Indian non-urban industry with its wide size offers a huge opportunity for invest mentors.

\section{THE EMERGENCE OF CAUSE RELATED MARKETING (CRM)}

CRM can be viewed as an appearance of the arrangement of corporate philanthropy and rational business interest. It is basically a marketing program that tries to achieve two objectives that are improve corporate performance and help worthy causes by linking fund raising for the benefit of a cause through the purchase of the firm's products and/or services. CRM programs is the indicative of the marketing thrust, contributions to charity through CRM do not come from its regular philanthropic foundation budget. A portion of the marketing budget that normally would have been expended for advertising and/or sales promotion is instead reserved for contribution to a cause on behalf of those customers who engage in revenue-producing transactions with the firm during a specified time period and comply with other terms of exchange. For example, during 1983, American Express Company launched a Cause Related Marketing Program (CRMP) in support of the renovation of the Statue of Liberty. American Express Company promised to donate a penny to the renovation for each use of its charge card and a dollar for each new card issued in the U.S. during the fourth quarter of 1983 . The results were great, the number of transaction rose $28 \%$ in relation to the same period the previous year, the number of card members rose $45 \%$ and the amount donated to the renovation of the Statue of Liberty was 1.7 million dollars.

\section{PROPOSED RESEARCH MODEL}

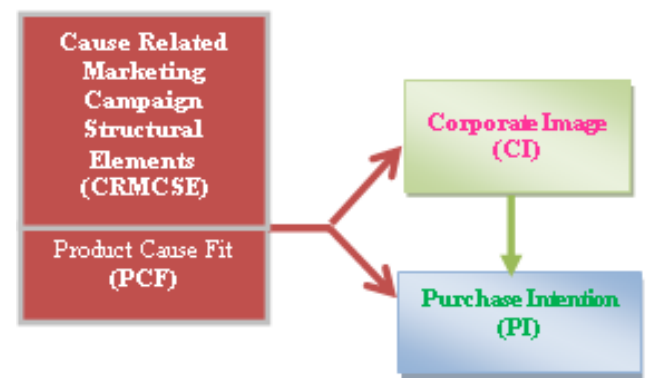

Figure 1. Proposed Research Model 


\section{REVIEW OF LITERATURE}

Varadarajan and Menon's (1988) article can be regarded as a seminal piece of work in the area of Cause Related Marketing. The aim of the article was to trace the development of the CRM concept, define CRM, discuss in detail the managerial and social aspects of CRM and provide suggestion for future research. This article has used a literary analysis and case studies. The authors define CRM as "the process of formulating and implementing marketing activities that are characterized by an offer from the firm to contribute a specified amount to a designated cause when customers engage in revenue providing exchanges that satisfy organizational and individual objectives." The salient feature of this definition of CRM is that there is an alliance between a firm and a not for profit organization, this alliance is based on a promise to support a cause, and the promise to support is linked to sales.

The effect of the compatibility of product and cause is proposed to influence consumer choice through associative learning (Shimp et al., 1991; Till and Nowak, 2000). Deepak, R. K. A et. al (2014), results suggest that an Ambush cause appeal can perform as well as a CRM appeal, and that the cause need not be closely associated to the marketer (Company-Cause Fit) to favorably influence perceptions of the audience. Cognitive consistency theories suggest that people desire consistency among beliefs or attitudes (Eagly and Chaiken, 1993). The popular press suggests that to maximize the results of CRM, sponsoring firms should select causes that are compatible with their identities and are com $\neg$ pelling to their target markets (Larson, 1994). Consumers believed that corporations "ought to" sponsor a cause that have a logical connection with their corporate activities. Indeed, consumers are more likely to be less skeptical, and the campaign is more likely to be viewed as successful when the cause is compatible or "matches" the firm (Gray, 2000). Kanthiah Alias Deepak et. al (2014), study reveals that the marketer too understand that there must be consistency on CRM message and repeated ads vastly reduces the Skeptism. The marketer should be cautious while designing the advertisement, it should be well organized and presenting the facts which can build the credibility of the audient. Pairings of firms with causes related to their core business are common. Their frequency in the marketplace and logical appeal are likely to increase consumer expectancies of high firm-cause compatibility pairings in CRM programs. This type of pairing between a firm and cause may lead consumers to suspect the firm is once again seeking to further its own objectives (e.g., increased sales, higher profits) and is using the CRM offer as a means for doing so. The low fit between a company and a cause led managers to fear sceptical reactions from consumers, who might view the company as exploiting the cause (Drumwright 1996). A close match is less likely to raise suspicion because a firm is not acting out of character with its prime directive; thus, attributions to the firm as strategic would be expected Fein's (1996). In CRM, the fit between product and cause may impact the success of CRM (Strahilevitz and Meyers, 1998). A significant number of sources within the CRM literature address the issue of fit between the cause and the product. They recommend that the company product should have a good fit with the cause that they hope to form an association with (Welsh 1999). Sponsorship researchers have highlighted the importance of congruence between sponsors and events (Speed and Thompson, 2000).

\section{RESEARCH METHODOLOGY}

In a democratic system, the role of the state is primary and most crucial in formulating and implementing the social and economic development programmes. The poor people are facing more problems. This is especially true in a country like India where a more number of weak sections exist at all the levels. It is difficult for government alone to take initiatives towards development activities. Hence other groups need to support the government through different ways. This essentiality paved way for the emergence of Cause Related Marketing Campaigns (CRMC). In this research we attempt to gain a better understanding of Cause Related Marketing (CRM) attributes by viewing a CRM campaign from a holistic perspective. By viewing the campaign from such a perspective we are able to gain valuable insight into the various affects and interactions that attributes have. The study specifically looks at; the consumers level of effort in the campaign, effect of product cause fit and the selection of causes. After designing the survey instrument, the scale was tested in the field. The study area has been identified as one of corporation provinces of Tamilnadu, India. The pilot was carried out in Kodambakkam Zone of Greater Chennai Corporation as two phases. There are 70 respondents were approached and 60 responses were used for reliability study using Cronbach's Alpha test. The result of the study was verified, and it was found to be favourable. "Multi-stage sampling is a further development of the principle of cluster sampling. Ordinarily multi-stage sampling is applied in big inquires extending to a considerable large geographical area. If we select randomly at all stages, we will have what is known as multi-stage random sampling design". In this research the Multi-Stage random sampling method of statistical probability sampling of was adopted. In Chennai Corporation, among the fifteen zones, the researcher selected Kodambakkam zone because it has highest population among fifteen zones in Greater Chennai Corporation. During the process of preparing a sample frame, from Kodambakkam zone, the researcher randomly selected five major divisions (Kodambakkam, Vadapalani, K.K Nagar, Saidapet, West Mambalam) out of 16 divisions. The researcher has personally drawn 110 draws from each division (5 divisions). The representative sample respondents were conducted by the field officer under the supervision of the researcher. In total 550 respondents were personally contacted to get a sample size of 450. For the study out of all the filled questionnaires, 90 questionnaires were used for further analysis from each division to a total of 450 respondents. 


\section{ANALYSIS}

Table-I: Mean difference between Age and Product Cause Fit (PCF)

\begin{tabular}{|c|c|c|c|c|c|c|c|}
\hline $\begin{array}{l}\text { Product } \\
\text { Cause Fit }\end{array}$ & Age & $\mathbf{N}$ & Mean & SD & $\mathbf{F}$ & $\mathbf{p}$ & DMRT \\
\hline \multirow{9}{*}{$\begin{array}{c}\text { Drinking Water \& } \\
\text { Provide Safe } \\
\text { Drinking Water } \\
(\mathrm{PCF}-1)\end{array}$} & $19-21$ & 120 & 3.4625 & .39648 & \multirow{9}{*}{77.060} & \multirow{9}{*}{.000} & \multirow{9}{*}{$\begin{array}{c}2,8,4 \mathrm{Vs} \\
5,7 \mathrm{Vs} \\
1 \mathrm{Vs} \\
3 \mathrm{Vs} 6\end{array}$} \\
\hline & $22-26$ & 83 & 4.2801 & .34790 & & & \\
\hline & $27-29$ & 77 & 3.0779 & .76548 & & & \\
\hline & $30-35$ & 66 & 4.0189 & .45002 & & & \\
\hline & $36-45$ & 55 & 3.8545 & .45565 & & & \\
\hline & $46-55$ & 34 & 2.2941 & .62906 & & & \\
\hline & $56-60$ & 6 & 3.7083 & .33229 & & & \\
\hline & Above 60 & 9 & 4.2222 & .52208 & & & \\
\hline & Total & 450 & 3.6072 & .74863 & & & \\
\hline \multirow{9}{*}{$\begin{array}{c}\text { Drinking Water \& } \\
\text { Education (PCF - } \\
\text { 2) }\end{array}$} & $19-21$ & 120 & 3.3167 & .63406 & \multirow{9}{*}{8.637} & \multirow{9}{*}{.000} & \multirow{9}{*}{$\begin{array}{l}4,5,2,8 \\
\text { Vs } 3,1 \\
\text { Vs } 7,6\end{array}$} \\
\hline & $22-26$ & 83 & 3.6867 & .76294 & & & \\
\hline & $27-29$ & 77 & 3.3994 & .74368 & & & \\
\hline & $30-35$ & 66 & 3.7652 & .61061 & & & \\
\hline & $36-45$ & 55 & 3.7091 & .63786 & & & \\
\hline & $46-55$ & 34 & 2.8603 & .80055 & & & \\
\hline & $56-60$ & 6 & 3.1667 & .94428 & & & \\
\hline & Above 60 & 9 & 3.5833 & .73951 & & & \\
\hline & Total & 450 & 3.4817 & .73572 & & & \\
\hline \multirow{9}{*}{$\begin{array}{c}\text { Drinking Water \& } \\
\text { Disaster Relief } \\
(\mathrm{PCF}-3)\end{array}$} & $19-21$ & 120 & 3.2313 & .80058 & \multirow{9}{*}{2.774} & \multirow{9}{*}{.008} & \multirow{9}{*}{$\begin{array}{c}7,2,5 \\
\text { Vs } 4,1,8 \\
\text { Vs } 3,6\end{array}$} \\
\hline & $22-26$ & 83 & 3.4789 & .78690 & & & \\
\hline & $27-29$ & 77 & 3.1591 & .90857 & & & \\
\hline & $30-35$ & 66 & 3.2652 & .85696 & & & \\
\hline & $36-45$ & 55 & 3.4273 & .74795 & & & \\
\hline & $46-55$ & 34 & 2.8897 & .86644 & & & \\
\hline & $56-60$ & 6 & 3.8750 & .58630 & & & \\
\hline & Above 60 & 9 & 3.1944 & .98249 & & & \\
\hline & Total & 450 & 3.2756 & .83787 & & & \\
\hline
\end{tabular}

Source: Primary Data

Null hypothesis $\mathrm{Ho}=$ There is no significant difference among age groups with respect to Product Cause Fit (PCF).

Alternate hypothesis $\boldsymbol{H A}=$ There is a significant difference among age groups with respect to Product Cause Fit (PCF).

The dependent variable Product Cause Fit (PCF) is subdivided into three aspects such as Drinking Water \& Provide Safe Drinking Water (PCF - 1), Drinking Water \& Education (PCF - 2), and Drinking Water \& Disaster Relief $(\mathrm{PCF}-3)$. Drinking Water \& Provide Safe Drinking Water $(\mathrm{PCF}-1)$ shows the $\mathrm{F}$ ratio 77.060 and $\mathrm{p}$ value is .000 ; Drinking Water \& Education ( $\mathrm{PCF}-2)$ shows the F ratio 8.637 and p value is .000; Drinking Water \& Disaster Relief $(\mathrm{PCF}-3)$ shows the F ratio 2.774 and $\mathrm{p}$ value is .008 . All the $\mathrm{p}$ values are less than 0.05 hence the null hypothesis is rejected. There is a significant difference among age groups with respect to Product Cause Fit (PCF). Therefore the result of DMRT and mean wise comparison of Drinking Water \&
Provide Safe Drinking Water (PCF - 1) shows the highest mean of 4.28 is with the age group of $22-26$ years; lowest mean value of 2.29 is with the age group of $46-55$ years; Drinking Water \& Education (PCF - 2) shows the highest mean of 3.76 is with the age group of $30-35$ years; lowest mean value of 2.86 is with the age group of $46-55$ years; Drinking Water \& Disaster Relief (PCF - 3) shows the highest mean of 3.87 is with the age group of $56-60$ years; lowest mean value of 2.88 is with the age group of $46-55$ years. It is found that the respondents significantly differ with respect to age groups towards Drinking Water \& Provide Safe Drinking Water $(\mathrm{PCF}-1)$, Drinking Water \& Education $(\mathrm{PCF}-2)$, Drinking Water \& Disaster Relief $(\mathrm{PCF}-3)$. It is noted that one way ANOVA result shows that Age of respondents moderately agree with respect to PCF - 1, PCF 2 , and PCF -3 . Among them the Age group of $22-26$ respondents in $\mathrm{PCF}-1$ are highly agreed. 
Role of Product Cause Fit in Cause Related Marketing Campaign Decisions

Table-II Mean difference between income and product cause fit (PCF)

\begin{tabular}{|c|c|c|c|c|c|c|c|}
\hline $\begin{array}{c}\text { Product Cause } \\
\text { Fit }\end{array}$ & Income & $\mathbf{N}$ & Mean & SD & $\mathbf{F}$ & $\mathbf{p}$ & DMRT \\
\hline \multirow{9}{*}{$\begin{array}{l}\text { Drinking Water } \\
\text { \& Provide Safe } \\
\text { Drinking Water } \\
\quad(\mathrm{PCF}-1)\end{array}$} & Up to Rs.5000 & 2 & 1.8750 & .53033 & \multirow{9}{*}{82.213} & \multirow{9}{*}{.000} & \multirow{9}{*}{$\begin{array}{c}6,7,8 \\
\text { Vs } 3,4 \\
\text { Vs } 5,2 \\
\text { Vs } 1\end{array}$} \\
\hline & Rs.5001 - Rs.10000 & 9 & 2.4167 & .96825 & & & \\
\hline & Rs.10001 - Rs. 15000 & 51 & 3.3578 & .37167 & & & \\
\hline & Rs. 15001 - Rs. 20000 & 61 & 3.2049 & .66850 & & & \\
\hline & Rs.20001 - Rs. 25000 & 75 & 2.7767 & .56886 & & & \\
\hline & Rs. 25001 - Rs.50000 & 87 & 4.2931 & .34567 & & & \\
\hline & Above Rs.50001 & 22 & 4.0114 & .43968 & & & \\
\hline & Nil & 143 & 3.9231 & .45601 & & & \\
\hline & Total & 450 & 3.6072 & .74863 & & & \\
\hline \multirow{9}{*}{$\begin{array}{l}\text { Drinking Water } \\
\text { \& Education } \\
(\mathrm{PCF}-2)\end{array}$} & Up to Rs.5000 & 2 & 2.5000 & 1.41421 & \multirow{9}{*}{10.054} & \multirow{9}{*}{.000} & \multirow{9}{*}{$\begin{array}{l}\text { All } \\
\text { Vs } 1\end{array}$} \\
\hline & Rs.5001 - Rs.10000 & 9 & 3.1111 & .85797 & & & \\
\hline & Rs.10001 - Rs. 15000 & 51 & 3.2892 & .62923 & & & \\
\hline & Rs.15001 - Rs.20000 & 61 & 3.1311 & .69163 & & & \\
\hline & Rs.20001 - Rs.25000 & 75 & 3.1800 & .69695 & & & \\
\hline & Rs. 25001 - Rs.50000 & 87 & 3.6897 & .75480 & & & \\
\hline & Above Rs.50001 & 22 & 3.7727 & .64968 & & & \\
\hline & Nil & 143 & 3.7238 & .64712 & & & \\
\hline & Total & 450 & 3.4817 & .73572 & & & \\
\hline \multirow{9}{*}{$\begin{array}{l}\text { Drinking Water } \\
\text { \& Disaster } \\
\text { Relief } \quad \text { (PCF } \\
-3)\end{array}$} & Up to Rs.5000 & 2 & 2.6250 & 1.23744 & \multirow{9}{*}{3.551} & \multirow{9}{*}{.001} & \\
\hline & Rs.5001 - Rs.10000 & 9 & 2.6111 & .51707 & & & \multirow{8}{*}{$\begin{array}{c}7,6,8,3 \\
4,5 \mathrm{Vs} \\
1,2\end{array}$} \\
\hline & Rs. 10001 - Rs. 15000 & 51 & 3.2402 & .86885 & & & \\
\hline & Rs. 15001 - Rs. 20000 & 61 & 3.0984 & .83076 & & & \\
\hline & Rs.20001 - Rs.25000 & 75 & 3.0367 & .88311 & & & \\
\hline & Rs.25001 - Rs.50000 & 87 & 3.4368 & .81074 & & & \\
\hline & Above Rs.50001 & 22 & 3.4432 & .64518 & & & \\
\hline & Nil & 143 & 3.4161 & .80761 & & & \\
\hline & Total & 450 & 3.2756 & .83787 & & & \\
\hline
\end{tabular}

Null hypothesis $\boldsymbol{H o}=$ There is no significant difference among Income groups with respect to Product Cause Fit (PCF).

Alternate hypothesis $\boldsymbol{H A}=$ There is a significant difference among Income groups with respect to Product Cause Fit (PCF).

The dependent variable Product Cause Fit (PCF) is subdivided into three aspects such as Drinking Water \& Provide Safe Drinking Water (PCF - 1), Drinking Water \& Education $(\mathrm{PCF}-2)$, and Drinking Water \& Disaster Relief $(\mathrm{PCF}-3)$. Drinking Water \& Provide Safe Drinking Water $(\mathrm{PCF}-1)$ shows the $\mathrm{F}$ ratio 82.213 and $\mathrm{p}$ value is .000 ; Drinking Water \& Education $(\mathrm{PCF}-2)$ shows the F ratio 10.054 and $\mathrm{p}$ value is .000; Drinking Water \& Disaster Relief $(\mathrm{PCF}-3)$ shows the $\mathrm{F}$ ratio 3.551 and $\mathrm{p}$ value is .001 . All the $\mathrm{p}$ values are less than 0.05 hence the null hypothesis is rejected. There is no significant difference among Income groups with respect to Drinking Water \& Provide Safe Drinking Water (PCF - 1), Drinking Water \& Education $(\mathrm{PCF}-2)$, and Drinking Water \& Disaster Relief $(\mathrm{PCF}-3)$. Therefore the result of DMRT and mean wise comparison of Drinking Water \& Provide Safe Drinking Water $(\mathrm{PCF}-1)$ shows the highest mean of 4.29 is with the Rs.25001 Rs.50000; lowest mean value of 1.87 is with the up to Rs.5000; Drinking Water \& Education (PCF - 2) shows the highest mean of 3.77 is with the above Rs.50001; lowest mean value of 2.50 is with the up to Rs.5000; Drinking Water \& Disaster Relief ( $\mathrm{PCF}-3$ ) shows the highest mean of 3.44 is with the above Rs.50001; lowest mean value of 2.61 is with the Rs.5001 - Rs.10000. 
It is found that the respondents are significantly differ with respect to Income towards Drinking Water \& Provide Safe Drinking Water (PCF - 1), Drinking Water \& Education $(\mathrm{PCF}-2)$, and Drinking Water \& Disaster Relief $(\mathrm{PCF}-3)$. It is noted that one way ANOVA result shows that Income of respondents moderately agree with respect to $\mathrm{PCF}-1, \mathrm{PCF}-$ 2 and PCF - 3. Among them the Rs.25001 - Rs.50000 income group of respondents in PCF - 1 are highly agreed.

Table-III Showing independent T-TEST between gender AND CRMCSE

\begin{tabular}{|c|c|c|c|c|c|c|}
\hline $\begin{array}{c}\text { Cause } \\
\text { Related } \\
\text { Marketing } \\
\text { Campaign } \\
\text { Structural } \\
\text { Elements } \\
\text { (CRMCSE) }\end{array}$ & Gender & $\mathbf{N}$ & Mean & $\begin{array}{c}\text { Std. } \\
\text { Deviation }\end{array}$ & $\mathbf{t}$ & Sig \\
\hline \multirow{2}{*}{$\begin{array}{l}\text { Product Cause } \\
\text { Fit }\end{array}$} & Male & $\begin{array}{l}27 \\
4\end{array}$ & $\begin{array}{l}3.419 \\
7\end{array}$ & .58657 & \multirow{2}{*}{$\begin{array}{l}-1.64 \\
0\end{array}$} & \multirow{2}{*}{.102} \\
\hline & Female & $\begin{array}{l}17 \\
6 \\
\end{array}$ & $\begin{array}{l}3.509 \\
5 \\
\end{array}$ & .53407 & & \\
\hline \multirow{2}{*}{$\begin{array}{l}\text { Organizational } \\
\text { Fit }\end{array}$} & Male & $\begin{array}{l}27 \\
4 \\
\end{array}$ & $\begin{array}{l}3.447 \\
4 \\
\end{array}$ & .54624 & \multirow{2}{*}{$\begin{array}{l}-1.97 \\
7\end{array}$} & \multirow{2}{*}{.049} \\
\hline & Female & $\begin{array}{l}17 \\
6 \\
\end{array}$ & $\begin{array}{l}3.552 \\
1 \\
\end{array}$ & .55152 & & \\
\hline \multirow{2}{*}{$\begin{array}{l}\text { Donation } \\
\text { Quantifiers }\end{array}$} & Male & $\begin{array}{l}27 \\
4 \\
\end{array}$ & $\begin{array}{l}3.203 \\
5 \\
\end{array}$ & .60282 & \multirow{2}{*}{$\begin{array}{l}-1.82 \\
6\end{array}$} & \multirow{2}{*}{.069} \\
\hline & Female & $\begin{array}{l}17 \\
6\end{array}$ & $\begin{array}{l}3.312 \\
0\end{array}$ & .63501 & & \\
\hline \multirow{2}{*}{ Donation Caps } & Male & $\begin{array}{l}27 \\
4 \\
\end{array}$ & $\begin{array}{l}3.455 \\
6 \\
\end{array}$ & .58240 & \multirow{2}{*}{$\begin{array}{l}-2.16 \\
4\end{array}$} & \multirow{2}{*}{.031} \\
\hline & Female & $\begin{array}{l}17 \\
6\end{array}$ & $\begin{array}{l}3.578 \\
1\end{array}$ & .59222 & & \\
\hline \multirow{2}{*}{$\begin{array}{l}\text { Donation } \\
\text { Deadlines }\end{array}$} & Male & $\begin{array}{l}27 \\
4 \\
\end{array}$ & $\begin{array}{l}3.532 \\
5 \\
\end{array}$ & .52432 & \multirow{2}{*}{-.317} & \multirow{2}{*}{.752} \\
\hline & Female & $\begin{array}{l}17 \\
6 \\
\end{array}$ & $\begin{array}{l}3.549 \\
2 \\
\end{array}$ & .57847 & & \\
\hline \multirow{2}{*}{ Cause Scope } & Male & $\begin{array}{l}27 \\
4\end{array}$ & $\begin{array}{l}3.440 \\
7\end{array}$ & .60216 & \multirow{2}{*}{$\begin{array}{l}-1.56 \\
3\end{array}$} & \multirow{2}{*}{.119} \\
\hline & Female & $\begin{array}{c}17 \\
6\end{array}$ & $\begin{array}{c}3.531 \\
7\end{array}$ & .60400 & & \\
\hline
\end{tabular}

Source: Primary Data

Null hypothesis $\boldsymbol{H o}=$ There is no significant difference between gender groups and Cause Related Marketing Campaign Structural Elements (CRMCSE).

Alternate hypothesis $\boldsymbol{H A}=$ There is a significant difference between gender groups and Cause Related Marketing Campaign Structural Elements (CRMCSE).

The dependent variable Cause Related Marketing Campaign Structural Elements is sub divided in to six sub factors such as Product Cause Fit (PCF), For-Profit Organization \& Non-Profit Organization Fit (OF), Donation Quantifiers (DQ), Donation Caps (DC), Donation Deadlines (DD) and Cause Scope (CS).Gender includes two groups such as male and female. As far as the factors Product Cause Fit shows the $t$ ratio -1.640 and $p$ value is .102; Organizational Fit shows the $\mathrm{t}$ ratio -1.977 and $\mathrm{p}$ value is .049; Donation Quantifiers shows the $t$ ratio -1.826 and $p$ value is .069 ; Donation Caps shows the $t$ ratio -2.164 and $p$ value is .031; Donation Deadlines shows the $t$ ratio -.317 and $p$ value is .752 and Donation Scope shows the $t$ ratio -1.563 and $p$ value is .119 . The $p$ value of
Product Cause Fit, Donation Quantifiers, Donation Deadlines, and Cause Scope are greater than 0.05 hence the hence the null hypothesis is accepted. There is no significant difference between Gender and Product Cause Fit, Donation Quantifiers, Donation Deadlines, and Cause Scope. The p value of Organizational Fit and Donation Caps are less than 0.05 hence the null hypothesis is rejected. There is a significant difference between Gender and Organizational Fit and Donation Caps. Further the mean wise comparison of Product Cause Fit shows the highest mean of 3.50 is with the gender group female; lowest mean value of 3.41 is with the gender group male; Organizational Fit shows the highest mean of 3.55 is with the gender group female; lowest mean value of 3.44 is with the gender group male; Donation Quantifiers shows the highest mean of 3.31 is with the gender group female; lowest mean value of 3.20 is with the gender group male; Donation Caps shows the highest mean of 3.57 is with the gender group female; 
lowest mean value of 3.45 is with the gender group male; Donation Deadlines shows the highest mean of 3.54 is with the gender group female; lowest mean value of 3.53 is with the gender group male; Cause Scope shows the highest mean of 3.53 is with the gender group female; lowest mean value of 3.44 is with the gender group male. It is found that the respondent's opinions not significantly differ with respect to their gender groups towards Product Cause Fit (PCF), Donation Quantifiers (DQ), Donation Deadlines (DD) and
Cause Scope (CS). The respondent's opinions significantly differ with respect to their gender groups towards For-Profit Organization\& Non-Profit Organization Fit (OF) and Donation Caps (DC). It is noted that T-Test result shows that Gender of respondents moderately agree with respect to CRMCSE factors. The Female respondents are highly agreed compared to Male respondents.

Table-IV:Relationships between crmcse and corporate image

\begin{tabular}{|c|c|c|c|c|}
\hline \multirow{2}{*}{ CRMCSE } & \multicolumn{4}{|c|}{ Corporate Image } \\
\cline { 2 - 5 } & Quality & Performance & Responsibility & Attractiveness \\
\hline PCF1 & .340 & .319 & .236 & $.114^{*}$ \\
\hline PCF2 & .563 & .413 & .323 & .170 \\
\hline PCF3 & .569 & .364 & .396 & .346 \\
\hline
\end{tabular}

Source: primary data * Significant at $5 \%$ level \& others are significant at $1 \%$ level

Null hypothesis $\mathrm{Ho}=$ There is no significant relationship between CRMCSE and Corporate Image.

Alternate hypothesis $\boldsymbol{H} \mathbf{1}=$ There is a significant relationship between CRMCSE and Corporate Image.

The Pearson correlation test was run on a sample of 450 employees' to know the relationship between the 18 components of CRMCSE and four components of Corporate Image. For the statistical purpose the CRMCSE is classified into 3 groups such as PCF1, PCF2, and PCF3. Likewise the Corporate Image is divided into four groups such as Quality, Performance, Responsibility and Attractiveness. Pearson correlation coefficient among all CRMCSE factors with respect to Quality, Performance, Responsibility and Attractiveness; $p$ value is 0.000 which is significant at $1 \%$ level and PCF - 1, with respect to Attractiveness is at $5 \%$ level. It is conclude that there is a significant relationship among all PCF - 1 with respect to Quality, Performance, Responsibility and Attractiveness.

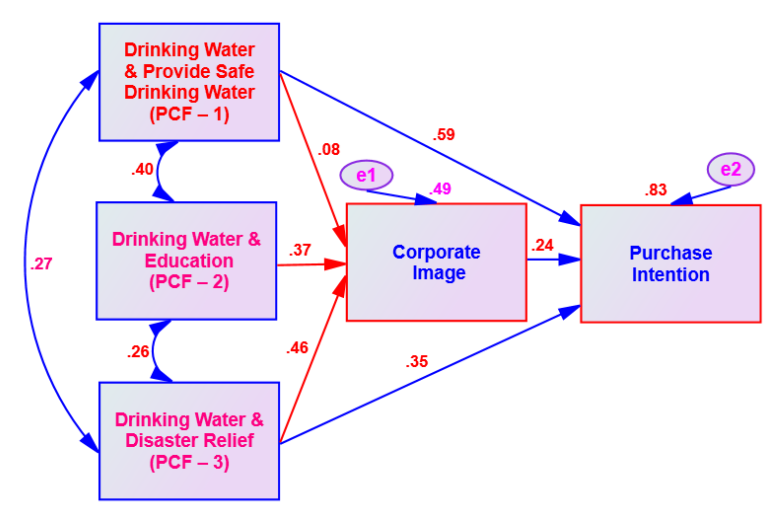

Figure 2: Product Cause Fit (PCF)
Table-V: model fit

\begin{tabular}{|c|c|c|c|c|c|c|c|c|}
\hline Variable & $\mathbf{X}^{2}$ & $\mathbf{p}$ & $\mathbf{R M S}$ & $\begin{array}{c}\mathbf{R M S E} \\
\mathbf{A}\end{array}$ & $\mathbf{G F I}$ & $\mathbf{A G F I}$ & $\mathbf{C F I}$ & $\mathbf{N F I}$ \\
\hline PCF & $\begin{array}{l}1.3 \\
3\end{array}$ & $\begin{array}{c}0.2 \\
4\end{array}$ & $\begin{array}{c}0.00 \\
4\end{array}$ & 0.02 & 0.99 & 0.98 & $\begin{array}{c}0.9 \\
9\end{array}$ & $\begin{array}{c}0.9 \\
9\end{array}$ \\
\hline
\end{tabular}

Source: Primary Data

Above table shows the model fit. The Chi square value is 1.332. P-value is 0.132. Good Fit Index is $0.997 \mathrm{AGF}$ is 0.983 , CFI is $0.998 \mathrm{NFI}$ is 0.995 . All these readings according to norms should be near one. All are very near to 1 so this model fit is acceptable. RMSEA value is 0.027 and RMS value is 0.004 . The expected norm value for RMSEA and RMS should be below 0.08 . This is also acceptable as a model fit.

Table-VI:Regression weights

\begin{tabular}{|c|c|c|c|c|c|c|c|}
\hline DV & Path & IV & Estimate & S.E & C.R. & B & p \\
\hline CI & $<--$ & PCF1 & .060 & .026 & 2.264 & .084 & .024 \\
\hline CI & $<--$ & PCF3 & .289 & .022 & 12.961 & .459 & .000 \\
\hline CI & $<--$ & PCF2 & .267 & .027 & 10.015 & .373 & .000 \\
\hline PI & $<--$ & PCF1 & .431 & .015 & 28.443 & .588 & .000 \\
\hline PI & $<--$ & PCF3 & .231 & .016 & 14.873 & .353 & .000 \\
\hline PI & $<--$ & TOTCI & .246 & .025 & 9.656 & .236 & .000 \\
\hline
\end{tabular}

Source: Primary Data 
Table-VII:Standardized total effects

\begin{tabular}{|c|c|c|c|c|c|}
\hline DV & Effect & PCF3 & PCF2 & PCF1 & TOTCI \\
\hline \multirow{3}{*}{ CI } & Direct & .459 & .373 & .084 & .000 \\
\cline { 2 - 6 } & Indirect & .000 & .000 & .000 & .000 \\
\cline { 2 - 6 } & Total & .459 & .373 & .084 & .000 \\
\hline
\end{tabular}

\section{Ho: PCF1 do not influence corporate image H1: PCF1 influence corporate image}

The standardized total effect of PCF1 over CI is 0.084 . The standardized direct effect is 0.084 and the standardized indirect effect is 0.000 . Through the path analysis, regression weight of the PCF1 over CI shows the estimator as 0.060 is positive, standard error is 0.026 the critical ratio is 2.264 and the Beta value is 0.084 which is $8 \%$. It can be stated that the influence of $\mathrm{PCF} 1$ over $\mathrm{CI}$ contribute to $8 \%$, the $\mathrm{p}$ value 0.024 is significant at $5 \%$ level lead to the rejection of Ho and acceptance of $\mathrm{H} 1$. This can be interpreted that the PCF1 influence CI.

\section{Ho: PCF2 do not influence corporate image H1: PCF2 influence corporate image}

The standardized total effect of PCF2 over CI is 0.373 . The standardized direct effect is 0.373 and the standardized indirect effect is 0.000 .Through the path analysis, regression weight of the PCF2 over CI shows the estimator as .267 is positive, standard error is .027 the critical ratio is 10.015 and the Beta value is .373 which is $37 \%$. It can be stated that the influence of PCF2 over CI contribute to $37 \%$, the p value .000 is significant at $1 \%$ level lead to the rejection of Ho and acceptance of $\mathrm{H} 1$. This can be interpreted that the PCF2 influence $\mathrm{CI}$.

\section{Ho: PCF3 do not influence corporate image H1: PCF3 influence corporate image}

The standardized total effect of PCF3 over CI is 0.459 . The standardized direct effect is 0.459 and the standardized indirect effect is 0.000.Through the path analysis, regression weight of the PCF3 over CI shows the estimator as .289 is positive, standard error is .022 the critical ratio is 12.961 and the Beta value is .459 which is $45 \%$. It can be stated that the influence of PCF2 over CI contribute to $45 \%$, the p value .000 is significant at $1 \%$ level lead to the rejection of Ho and acceptance of H1. This can be interpreted that the PCF3 influence CI.

\section{FINDINGS}

It is found that the respondents significantly differ with respect to age groups towards Drinking Water \& Provide Safe Drinking Water $(\mathrm{PCF}-1)$, Drinking Water \& Education $(\mathrm{PCF}-2)$, Drinking Water \& Disaster Relief $(\mathrm{PCF}-3)$. It is noted that one way ANOVA result shows that Age of respondents moderately agree with respect to $\mathrm{PCF}-1, \mathrm{PCF}-$ 2 , and $\mathrm{PCF}-3$. Among them the Age group of $22-26$ respondents in PCF - 1 are highly agreed. It is found that the respondents significantly differ with respect to Occupation towards Drinking Water \& Provide Safe Drinking Water $(\mathrm{PCF}-1) \&$ Drinking Water \& Education $(\mathrm{PCF}-2)$ and the respondents not significantly differ with respect to Occupation towards Drinking Water \& Disaster Relief (PCF - 3). It is noted that one way ANOVA result shows that Occupation of respondents moderately agree with respect to $\mathrm{PCF}-1, \mathrm{PCF}-2$, and $\mathrm{PCF}-3$. Among them the Business group of respondents in PCF - 1 is highly agreed. It is found that the respondents are significantly differ with respect to Income towards Drinking Water \& Provide Safe Drinking Water $(\mathrm{PCF}-1)$, Drinking Water \& Education $(\mathrm{PCF}-2)$, and Drinking Water \& Disaster Relief ( $\mathrm{PCF}-3)$. It is noted that one way ANOVA result shows that Income of respondents moderately agree with respect to $\mathrm{PCF}-1, \mathrm{PCF}-2$ and $\mathrm{PCF}-$ 3. Among them the Rs. 25001 - Rs.50000 income group of respondents in PCF - 1 are highly agreed. It is found that the respondent's opinions not significantly differ with respect to their gender groups towards Product Cause Fit (PCF), Donation Quantifiers (DQ), Donation Deadlines (DD) and Cause Scope (CS). The respondent's opinions significantly differ with respect to their gender groups towards For-Profit Organization\& Non-Profit Organization Fit (OF) and Donation Caps (DC). It is noted that T-Test result shows that Gender of respondents moderately agree with respect to CRMCSE factors. The Female respondents are highly agreed compared to Male respondents. It is found that there is a significant relationship among all CRMCSE factor with respect to Corporate Image (Quality, Performance, Responsibility and Attractiveness). The factor PCF - 1, PCF $-2, \mathrm{PCF}-3$ are highly correlated Quality. PCF $-1, \mathrm{PCF}-2$ and $\mathrm{PCF}-3$ are influencing Corporate Image and PCF - 1, $\mathrm{PCF}-3$ and Corporate Image are influencing Purchase Intention.

\section{SUGGESTIONS}

Among the Cause - 1, Cause - 2, and Cause - 3, the Cause 1 (Provide Safe Drinking Water) is highly influences consumer's purchase intention. Hence the researcher recommends the drinking water manufactures to choose the Cause - 1 (Provide Safe Drinking Water) for their Cause Related Marketing Campaign. Further the researcher found that there is a relationship between Product Cause Fit (PCF) and Corporate Image. Also Corporate Image has direct influence on Purchase Intention. In this way researcher suggest the drinking water manufactures to concentrate more while selecting causes for Cause Related Marketing Campaign which determines the corporate image in the minds of consumers.

\section{MANAGERIAL IMPLICATION}

The result of this study provides corporates with a better understanding about the Cause Related Marketing Campaign Structural Elements (CRMCSE). This study helps managers to understand the level of influence of elements, which means the ranking of importance of elements and the weight it holds. 
Further, the corporates can understand the influence of elements on corporate image. Therefore mangers can create a good image in the minds of consumer by assembling the elements properly and through that they can influence consumer's purchase intention. The study provide a clear insight to managers about the selection cause. This information helps the corporates to construct a successful Cause Related Marketing Campaign (CRMC).

\section{CONCLUSION}

The research started with the aim to get a better understanding of Cause Related Marketing Campaigns (CRMC) from a whole perspective. In order get a complete understanding of the Cause Related Marketing Campaigns (CRMC), the element namely Product Cause Fit was studied. The Campaigns showed to the consumers like, $(\mathrm{PCF}-1, \mathrm{PCF}$ -2 , and PCF -3 ) in order to understand the consumer's response. The consumers are moderately agreed with all three types of models. Hence their response to Cause Related Marketing Campaigns (CRMC) is moderate based on the mean values. Further the researcher found that there is a relationship between Product Cause Fit and Corporate Image. Also Corporate Image has direct influence on Purchase Intention. In this way researcher suggest the corporates to concentrate more while determining cause for Cause Related Marketing Campaign which determines the corporate image in the minds of consumers.

\section{REFERENCES}

1. Drumwright, Minette E. 1996. "Company Advertising With a Social Dimension: The Role of Noneconornic Criteria." Journal of Marketing 60 (October): 71-87.

2. Deepak, R. K. A., \& Kathiravan, D. (2014). Relative Efficacy Ambush Marketing and Cause Related Marketing. Asia Pacific Journal of Marketing \& Management Review ISSN, 2319, 2836. http://indianresearchjournals.com/pdf/APJMMR/2014/July/11.pdf

3. Eagly, A. H., \& Chaiken, S. (1993). The psychology of attitudes. Fort Worth, TX: Harcourt Brace Jovanovich College Publishers.

4. Fein, Steven. 1996. "Effects of Suspicion on Attributional Thinking and the Correspondence Bias." Journal of Personality and Social Psychology 70 (6): 1164-1184.

5. Kanthiah Alias Deepak et. al (2014), Enactment of Skeptism in Cause affiliated Marketing, Asian Journal of Research in Business Economics \& Management, Vol. 4, Issue. 8, Aug - 2014, 160 - 169. http://aijsh.org/setup/business/paper874.pdf

6. Larson, J. (1994), "If you're not committed, don't bother", American Demographics, Vol. 16 No. 12, pp. 16-18.

7. Shimp, T.A., Stuart, E.W. and Engle, R.W. (1991), "A program of classical conditioning experiments testing variations in the conditioned stimulus and context", Journal of Consumer Research, Vol. 18, June, pp. 1-12.

8. Speed, R. and Thompson, P. (2000), "Determinants of sports sponsorship response", Academy of Marketing Science Journal, Vol. 28 No. 2, p. 226

9. Strahilevitz, M. and Myers, J.G. (1998), "Donations to charity as purchase incentives: how well they work may depend on what you are trying to sell", Journal of Consumer Research, Vol. 24 No. 2, pp. 434-46.

10. Welsh, J, (1999), Good Cause, Good Business, Harvard Business Review, September - October, pp. 21-24. 